\title{
Telecommunting: The Problems \& Challenges During Covid-19 (2020)
}

\author{
Dr. Rushina Khan * \\ Deogiri Institute of Management Studies
}

\author{
Dr. Siddiqui Lubna Javed Hasan** \\ Millennium Institute of Management
}

\begin{abstract}
The 'Telecommuting' concept is not a recent trend in India. The idea has developed since Work from Home seen as the new element in human resource strategy. Flexible employment can be implemented in India by considering technology, rules set up by employers and employees' preference. Telecommuting, where individuals primarily work from sites that are miles away from central offices, is making inroads into India's work practices. This practice carries several promises but also confronts many hurdles in its adoption.

The paper specially focus on the problems and challenges of telecommuting during this crucial period of COVID 19 where every employee is forced to work from home. The major problems it confronts include structural and cultural issues such as lack of adequate infrastructure, lack of motivation and organizational culture of command and control along with household congestion and non reliability. This article also proposes numerous conceivable arrangements \& recommendations to empower working from home.
\end{abstract}

Keywords: Telecommuting, Technology, COVID 19, congestion, internet connectivity

\section{INTRODUCTION}

Telework is variously referred to as "telecommuting", "work from home", "e-work", "virtual work", "and remote work", "distance working", "distributed work", "work shifting" or "flexible working". Telecommuting is the act of working at a remote location, usually at home, rather than traveling to and from an office. Telecommuters typically telecommute one to three days a week and commute to the office for the balance of the time. The advantages of Telecommuting for employees are decrease in time and stress of commuting in congested areas and increase in flexibility in coping with family demands. But the potential drawbacks may be absence of social contact what the normal office provides. Technology development in India is in line with India's goal to attain high income status in 2024. High technology is a priority to India to improve the economic growth. India rose from 48th put in 2018 to 44th rank this year as the nation has progressed generally in all components information, innovation and future preparation as compared to the previous year's ranking. India has advanced four places to 44th position in terms of digital competitiveness in the world as the country has made improvement in terms of knowledge and future readiness to adopt and explore digital technologies, according to a global report. The increasing of smart phone users allows them to communicate through email, online message and video.

"India advanced four places to 44th position in 2019, with the biggest improvement in the technology sub-factor level, holding first position in telecommunications investment," according to the IMD World Digital Competitiveness Ranking 2019 (WDCR). The US was ranked as the world's most digitally competitive economy, followed by Singapore in the second place. Sweden was ranked third on the list, followed by Denmark and Switzerland in the 4th and 5th place, respectively.

\section{OBJECTIVE OF STUDY:}

1. To study telecommuting and its overall impact on behavior of employees during Covid-19.

2. To study the problems and challenges they faced during this quarantine/lockdown period.

3. To study the various factors that helped them to work effectively.

\section{HYPOTHESIS:}

Hypothesis No. 1

$\mathrm{H}_{0}$ : There is unfavorable relationship between High Performance and poor internet connection.

$\mathrm{H}_{1}$ : There is favorable relationship between High Performance and poor internet connection.

\section{Hypothesis No. 2}

$\mathrm{H}_{0}$ : There is no significant relationship of household congestion (noise) and having kids

H1: There is a significant relationship of household congestion (noise) and having kids.

\section{RESEARCH METHODOLOGY}

This study further dealt with sample, research tools, and administration of the tools and analysis of data. An incidental sample of 200 respondents was collected from the full time working professionals. Care was taken that tests must be reliable and valid to a considerable extent. The paper deals with the analytical study using mean, ANOVA \& Chi square analysis 


\section{LITERATURE REVIEW}

1. Acharya, P., Mahanty, B. (2007). Manpower shortage crisis in Indian information technology industry, Indian IT industry has drawn attention of the world for its spectacular growth over last decade. Concurrent emergence of global economy and boom in Information Technology industry has brought unexpected opportunity for India. Because of a variety of reasons, Indian IT industry has become globally competitive and a frontrunner in software services exports. However India's position as a leading IT nation could be seriously endangered soon for want of adequate skilled manpower. This paper assesses the manpower scenario of India's IT industry and its effect on the industry's long term prospects.

2. André Fernandes Bernardino I; Karina De Déa Roglio II; Jansen Maia Del Corso III (August-2012), this article is to identify guidelines for the implementation and management of telecommuting, as an alternative to overcome the shortage of qualified professionals in Information Technology (IT). The results, based on a case study of a Brazilian subsidiary of a multinational organization that provides IT services, show that telecommuting (1) contributes to attracting and retaining qualified professionals in IT, (2) should be based on trustworthy relationships, (3) has to be supported by a strategy of decentralization of both structure and organizational assets.

3. Bailey, D.E., Kurland, N.B. (2002). A review of Telework research, findings, new directions, and lessons for the study of modern work., this paper focuses on Telework has inspired research in disciplines ranging from transportation and urban planning to ethics, law, sociology, and organizational studies. In our review of this literature, we seek answers to three questions: who participates in telework, why they do, and what happens when they do? Who teleworks remains elusive, but research suggests that male professionals and female clerical workers predominate. We suggest three steps for future research may provide richer insights: consider group and organizational level impacts to understand who telework affects, reconsider why people telework, and emphasize theory-building and links to existing organizational theories.

4. Golden, T.D., Veiga, J.F. (2005). The impact of extent of telecommuting on job satisfaction: Resolving inconsistent findings, Journal of Management, in this study, the authors attempt to resolve these inconsistent findings by hypothesizing a curvilinear, inverted U-shaped relationship between the extent of telecommuting and job satisfaction. Using hierarchical regression analysis on a sample of 321 professional-level employees, their findings suggest a curvilinear link between extent of telecommuting and job satisfaction, with satisfaction appearing to plateau at more extensive levels of telecommuting.

5. According to Mamaghani, Farrokh (2012), Telecommuting has attracted a lot of attention over the past decade due to its impact on its workers, businesses, and society. Telecommuting can be defined as the practice of working from remote locations using the information and telecommunications technology (ICT). The terms telecommuting and telework can be used interchangeably.

VI. DATA ANALYSIS \& INTERPRETATIONS

\begin{tabular}{|c|c|c|c|c|}
\hline Sr.no. & \multicolumn{2}{|c|}{ Demographic Characteristics } & Frequency & Percentage \\
\hline \multirow{5}{*}{1} & \multirow{5}{*}{ Age-Group } & $18-25$ & 76 & $38 \%$ \\
\hline & & $25-35$ & 61 & $30.50 \%$ \\
\hline & & $35-45$ & 43 & $21.50 \%$ \\
\hline & & $45-55$ & 16 & $8.00 \%$ \\
\hline & & $55 \&$ Above & 4 & $2.00 \%$ \\
\hline \multirow{2}{*}{2} & \multirow{2}{*}{ Gender } & Male & 135 & $67.50 \%$ \\
\hline & & Female & 65 & $32.50 \%$ \\
\hline \multirow{2}{*}{3} & \multirow{2}{*}{ Marital Status } & Single & 103 & $51.50 \%$ \\
\hline & & Married & 97 & $48.50 \%$ \\
\hline \multirow{4}{*}{4} & \multirow{4}{*}{ Education } & HSC & 7 & $3.5 \%$ \\
\hline & & Graduation & 47 & $23.50 \%$ \\
\hline & & PG & 126 & $63.00 \%$ \\
\hline & & Others & 20 & $10.00 \%$ \\
\hline \multirow{4}{*}{5} & \multirow{4}{*}{ Occupation } & Private & 120 & $60.0 \%$ \\
\hline & & Government & 14 & $7.00 \%$ \\
\hline & & Students & 32 & $16.00 \%$ \\
\hline & & Others & 34 & $17.00 \%$ \\
\hline \multirow{4}{*}{6} & \multirow{4}{*}{ Annual Income } & $150000-250000$ & 85 & $42.5 \%$ \\
\hline & & $250001-350000$ & 31 & $15.50 \%$ \\
\hline & & $350001-450000$ & 22 & $11.00 \%$ \\
\hline & & $450001 \&$ Above & 62 & $31.00 \%$ \\
\hline \multicolumn{3}{|c|}{ TOTAL } & 200 & 100 \\
\hline \multicolumn{5}{|c|}{ Sources: Primary dataNote: Total Number of Respondent(T.N.R) } \\
\hline
\end{tabular}




\section{Interpretations:}

Table 1 reveals that general profile of respondents in the study area. As regards the age of the responders $38 \%$ of the respondents are aged 18-25 group, 31\% respondents are from 25-35 age group, $21 \%$ respondents are from 35-45 age group , $8 \%$ from $45-55$ age group and $2 \%$ respondents from $55 \&$ above.

An analysis of gender classification reveals that $68 \%$ approximately from male and $32 \%$ respondents are female. The study reveals that $49 \%$ are married. An analysis of education qualification revealed that about $4 \%$ respondents are higher secondary level, about $86 \%$ respondents ranging from graduate and Post graduate level. Others are stated to be Doctorate and post doctorate. An empirical classification and its analysis revealed that $60 \%$ respondents are employed in some private organization, $7 \%$ respondents are government employees and $33 \%$ are from students and others respectively.

An analysis of their income revealed that about $43 \%$ respondent's annual income is between 1.5 lac- 2.5 lac and $31 \%$ respondents were found to have annual income of 450000 above.

Q1. Self Motivation while working at Home

\begin{tabular}{|c|l|c|c|c|c|c|c|}
\hline Sr.no. & \multicolumn{1}{|c|}{ Parameters } & $\begin{array}{c}\text { Strongly } \\
\text { Agree }\end{array}$ & Agree & Neutral & Disagree & $\begin{array}{l}\text { Strongly } \\
\text { Disagree }\end{array}$ & TOTAL \\
\hline & $\begin{array}{l}\text { Feel Self motivated while } \\
\text { working from home } \\
\text { (telecommuting) for first week }\end{array}$ & 69 & 48 & 36 & 24 & 23 & 200 \\
\cline { 2 - 7 } 1 & $\begin{array}{l}\text { Feel Self motivated while } \\
\text { working from home } \\
\text { (telecommuting) for second } \\
\text { week }\end{array}$ & 24 & 89 & 39 & 35 & 13 & 200 \\
\cline { 2 - 7 } & $\begin{array}{l}\text { Feel Self motivated while } \\
\text { working from home } \\
\text { (telecommuting) after 15 days }\end{array}$ & 30 & 50 & 21 & 27 & 72 & 200 \\
\hline
\end{tabular}

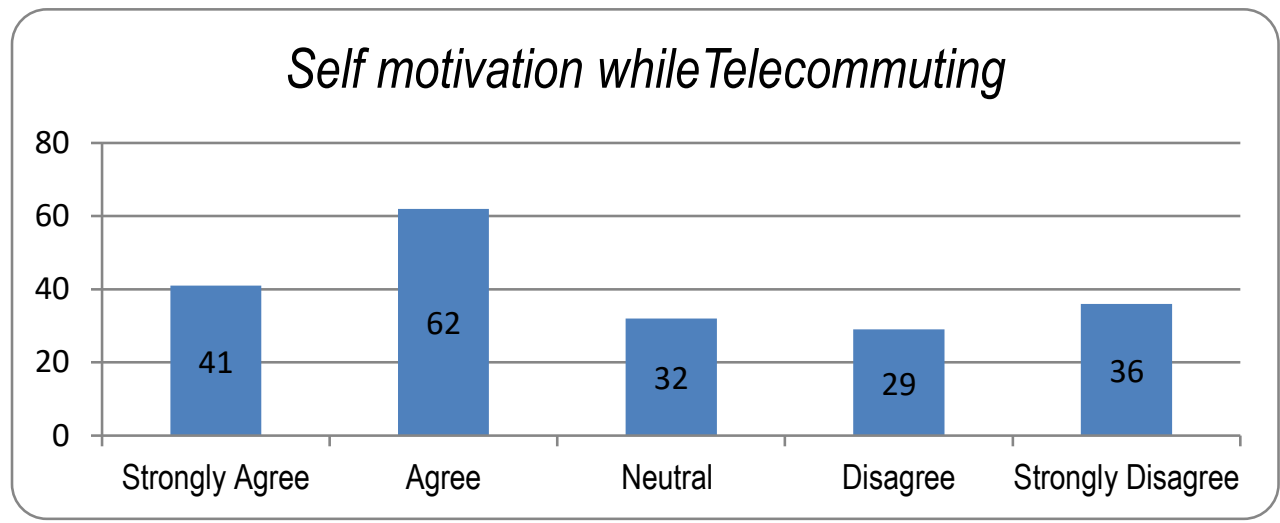

Interpretation:

From the above table, it can be revealed that in first week the employees were strongly agreeing on telecommuting, in the second week they were agreeing and after 15 days employees were strongly disagreeing from working at home due to many reasons.

It can be inferred on the basis of the averages of the sample, the majority of respondents were read to work from home due to the health issues that population is facing due to COVID-19.

Q2. Organizational Skills \& Job Description

\begin{tabular}{|c|l|c|c|c|c|c|c|}
\hline Sr.no. & \multicolumn{1}{|c|}{ Parameters } & $\begin{array}{c}\text { Strongly } \\
\text { Agree }\end{array}$ & Agree & Neutral & Disagree & $\begin{array}{c}\text { Strongly } \\
\text { Disagree }\end{array}$ & TOTAL \\
\hline 1 & $\begin{array}{l}\text { High level of job } \\
\text { knowledge and } \\
\text { skill is required } \\
\text { for } \\
\text { telecommuting }\end{array}$ & 48 & 76 & 24 & 30 & 22 & 200 \\
\hline 2 & $\begin{array}{l}\text { It gives me } \\
\text { Independence \& } \\
\text { confidence }\end{array}$ & 39 & 81 & 33 & 27 & 20 & 200 \\
\hline
\end{tabular}




\begin{tabular}{|c|c|c|c|c|c|c|c|}
3 & $\begin{array}{l}\text { Provides Comfort } \\
\text { with solitude }\end{array}$ & 54 & 69 & 41 & 22 & 14 & 200 \\
\hline \multicolumn{8}{|c|}{ Source: Primary Data (T.N.R)-March 2020 } \\
\hline AVERAGE & $\mathbf{4 7}$ & $\mathbf{7 5}$ & $\mathbf{3 3}$ & $\mathbf{2 6}$ & $\mathbf{1 9}$ & $\mathbf{2 0 0}$ \\
\hline
\end{tabular}

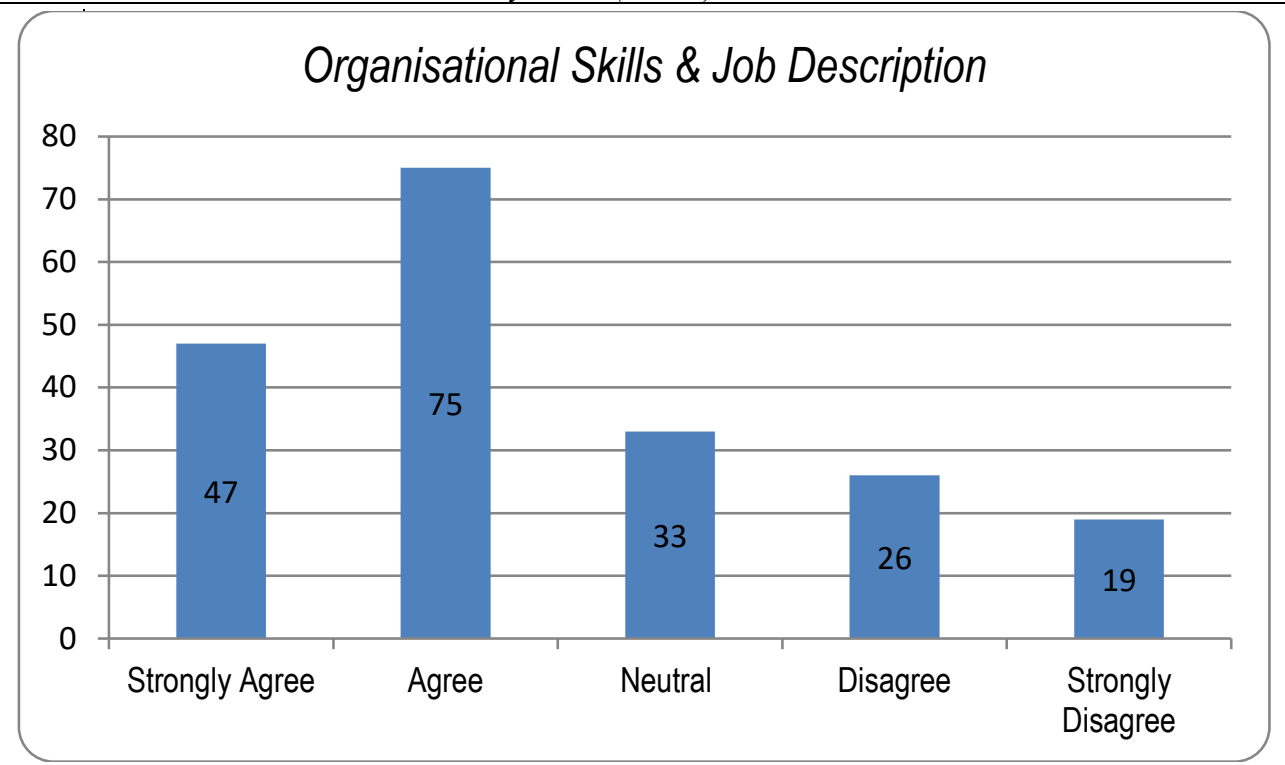

\section{Interpretation:}

It was observed that $47 \%$ of respondents strongly agree that telecommuting has improved organizational skills \& job description, $75 \%$ have agreed, $33 \%$ are neutral, $26 \%$ have disagreed and $19 \%$ have strongly disagreed.

Q3. Time Management \& Reliability

\begin{tabular}{|c|c|c|c|c|c|c|c|}
\hline Sr.no. & Parameters & $\begin{array}{c}\text { Strongly } \\
\text { Agree }\end{array}$ & Agree & Neutral & Disagree & $\begin{array}{l}\text { Strongly } \\
\text { Disagree }\end{array}$ & TOTAL \\
\hline 1 & $\begin{array}{l}\text { Help me in Time mgt \& } \\
\text { organization skills }\end{array}$ & 41 & 58 & 48 & 31 & 22 & 200 \\
\hline 2 & $\begin{array}{l}\text { Level of Concentration } \\
\text { increases }\end{array}$ & 29 & 50 & 49 & 48 & 24 & 200 \\
\hline 3 & $\begin{array}{l}\text { Help build Strong } \\
\text { communication skills }\end{array}$ & 29 & 61 & 56 & 36 & 18 & 200 \\
\hline 4 & $\begin{array}{l}\text { telecommuting has helped } \\
\text { me to spend more time on } \\
\text { my objectives and tasks }\end{array}$ & 21 & 80 & 41 & 34 & 24 & 200 \\
\hline \multirow[t]{2}{*}{5} & $\begin{array}{l}\text { Reduces Trustworthiness } \\
\text { and reliability }\end{array}$ & 34 & 67 & 57 & 26 & 16 & 200 \\
\hline & AVERAGES & 31 & 63 & 50 & 35 & 21 & 200 \\
\hline
\end{tabular}

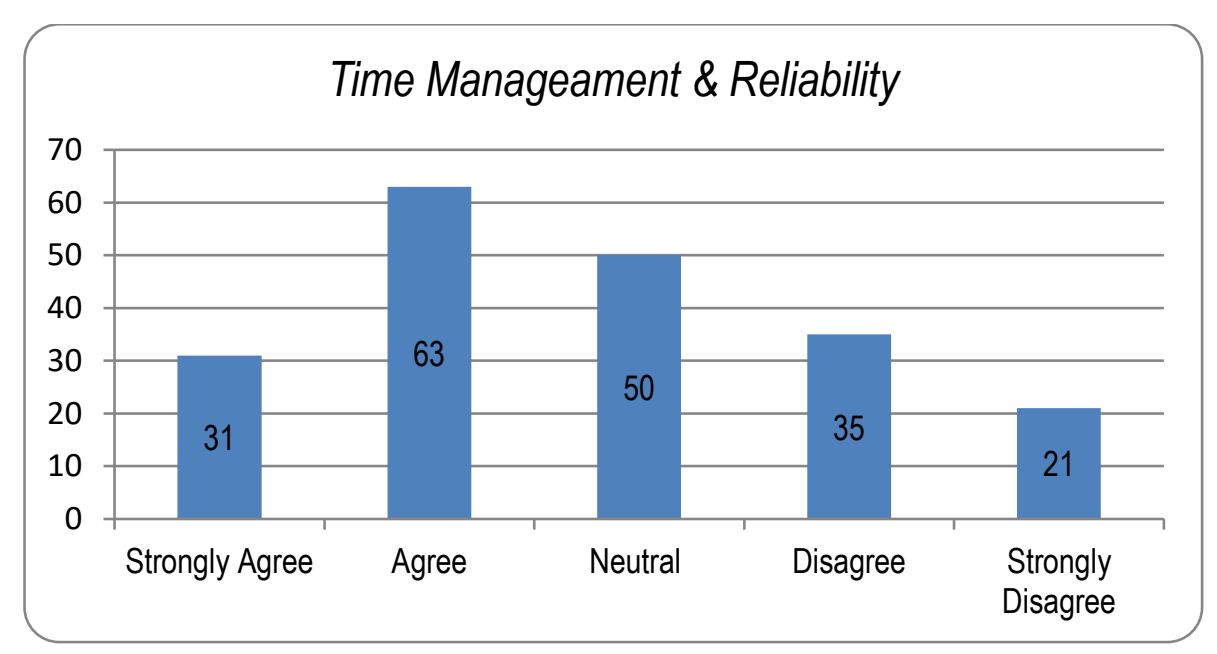




\section{Interpretation:}

It was interpreted that telecommuting has helped the respondents in time management, Increase in concentration, spending more time on objectives but reduces trustworthiness \& Reliability.

Q4. Team Spirit \& Problems faced while telecommuting

\begin{tabular}{|c|l|c|c|c|c|c|c|}
\hline Sr.no. & \multicolumn{1}{|c|}{ Parameters } & $\begin{array}{c}\text { Strongly } \\
\text { Agree }\end{array}$ & Agree & Neutral & Disagree & $\begin{array}{c}\text { Strongly } \\
\text { Disagree }\end{array}$ & TOTAL \\
\hline 1 & Lack of team spirit & 58 & 65 & 38 & 17 & 22 & 200 \\
\hline 2 & $\begin{array}{l}\text { Finding it difficult to } \\
\text { follow a disciplined } \\
\text { work routine }\end{array}$ & 56 & 65 & 50 & 13 & 16 & 200 \\
\hline 3 & $\begin{array}{l}\text { Feeling of } \\
\text { disconnectedness from } \\
\text { workplace arises }\end{array}$ & 60 & 59 & 46 & 21 & 14 & 200 \\
\hline 4 & $\begin{array}{l}\text { Lack of stationery and } \\
\text { equipments (printers } \\
\text { etc.) creates problems }\end{array}$ & 72 & 49 & 29 & 26 & 24 & 200 \\
\hline 5 & $\begin{array}{l}\text { Increased level of } \\
\text { irritation due to lack of } \\
\text { face to face meetings }\end{array}$ & 47 & 50 & 50 & 25 & 28 & 200 \\
\hline
\end{tabular}

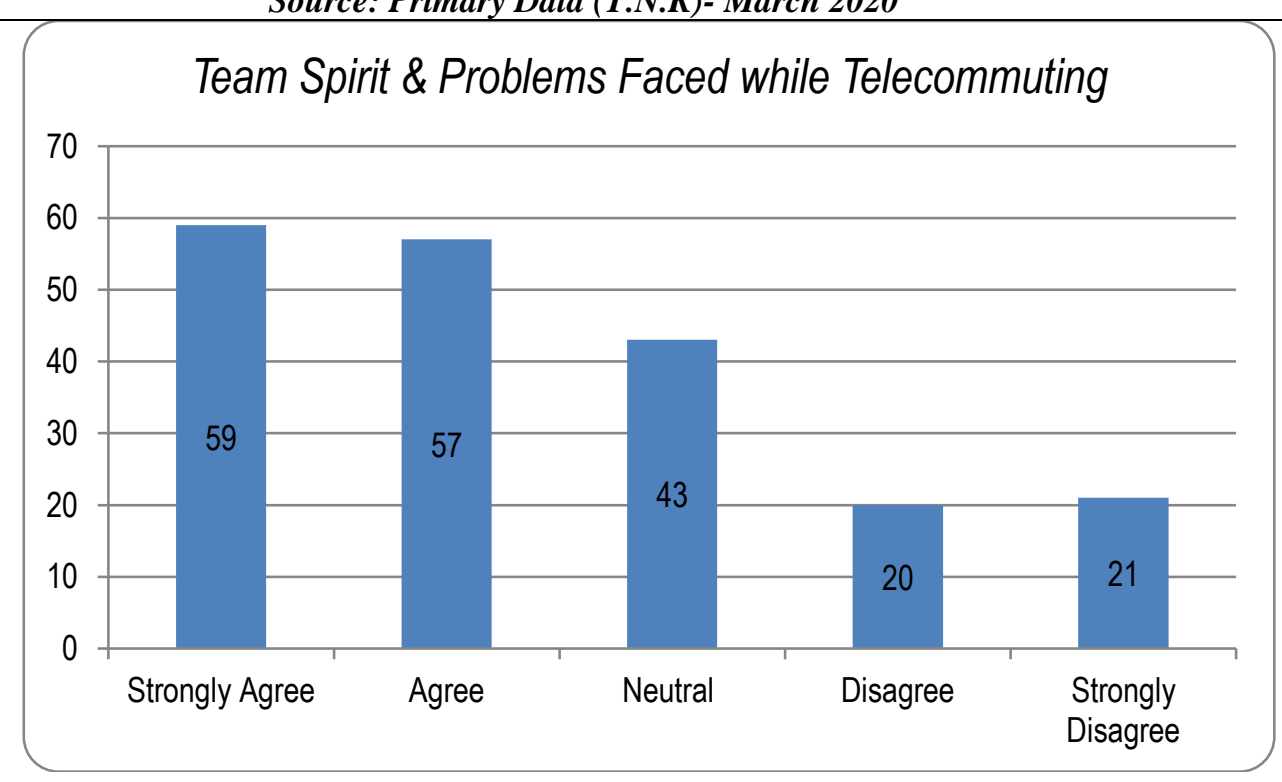

Interpretation:

It was interpreted that majority of respondents strongly agree that telecommuting lacks team spirit, it's difficult to follow a disciplined work routine, feel disconnected from workplace \& irritation due to lack of face to face meeting

\section{Hypothesis No. 1}

$\mathrm{H}_{0}$ : There is unfavorable relationship between High Performance and poor internet connection.

$\mathrm{H}_{1}$ : There is favorable relationship between High Performance and poor internet connection.

\begin{tabular}{|c|c|c|c|c|}
\hline \multicolumn{5}{|c|}{ ANOVA } \\
\hline Source of Variation & Sum of Squares & Degree of Freedom & Mean Square & F-Ratio \\
\hline Between Samples & 3824 & 4 & 956 & 5.9 \\
\hline Within samples & 1296 & 8 & 162 & 5.9 \\
\hline
\end{tabular}




\section{Interpretation:}

From the above table, for 4 degree of freedom between the samples $\& 8$ degree of freedom within the sample, the critical value of $\mathrm{F}$ at $5 \%$ of level of significance is 3.84. The calculated value is greater than the table value i.e. 5.90 > 3.84. Therefore the null hypothesis is rejected.

It can be inferred, that there is a favorable relationship between high performance and poor internet connection.

\section{Hypothesis No. 2}

$\mathrm{H}_{0}$ : There is no significant difference of household congestion (noise) and having kids

$\mathrm{H}_{1}$ : There is a significant relationship of household congestion (noise) and having kids.

Contingency Table of Observed Frequency

\begin{tabular}{|c|l|c|c|c|}
\hline Sr.no. & No. of Kids & Yes & No & Total \\
\hline 1 & NIL & 56 & 52 & 108 \\
\hline 2 & ONE & 25 & 14 & 39 \\
\hline 3 & TWO & 39 & 4 & 43 \\
\hline 4 & THREE & 8 & 2 & 10 \\
\hline \multicolumn{2}{r|}{ Total } & $\mathbf{1 2 8}$ & $\mathbf{7 2}$ & $\mathbf{2 0 0}$ \\
\hline
\end{tabular}

Expected Frequencies $=$ Row Total $x$ Column Total/ Grand Total

Contingency Table of Expected Frequency

\begin{tabular}{|c|l|c|c|c|}
\hline Sr.no. & \multicolumn{1}{|c|}{ No. of Kids } & YesX & No & Total \\
\hline 1 & Nil & 69.12 & 38.88 & 108 \\
\hline 2 & One & 24.96 & 14.04 & 39 \\
\hline 3 & Two & 27.52 & 15.48 & 43 \\
\hline 4 & Three & 6.4 & 3.6 & 10 \\
\hline & Total & 128 & 72 & 200 \\
\hline
\end{tabular}

Chi square Calculation: - $\mathrm{x}^{2}$

Computation of Value of Chi-Square

\begin{tabular}{|c|c|c|c|}
\hline $\mathrm{O}$ & $\mathrm{E}$ & $\mathrm{O}-\mathrm{E}$ & $(\mathrm{O}-\mathrm{E}) 2 / \mathrm{E}$ \\
\hline 176 & 187.95 & -13.12 & 0 \\
\hline 15 & 12.75 & 0.04 & 4.78 \\
\hline 344 & 327.57 & 11.48 & 0.4 \\
\hline 2 & 8.72 & 1.6 & 4.42 \\
\hline 104 & 92.05 & 13.12 & 0 \\
\hline 4 & 6.24 & -0.04 & 8.5 \\
\hline 144 & 160.43 & -11.48 & 0.71 \\
\hline 11 & 4.27 & -1.6 & $\mathbf{2 1 . 3}$ \\
\hline
\end{tabular}

$$
\begin{gathered}
\boldsymbol{x} \mathbf{2}=\sum \quad(\boldsymbol{O} \boldsymbol{i j}-\boldsymbol{E i j}) \quad \mathbf{2} \div \boldsymbol{E}=\mathbf{2 1 . 3} \\
\text { Degree of Freedom df }=(3-1) *(2-1) \\
\text { Df }=2
\end{gathered}
$$

Level of significance: $\mathrm{a}=5 \%=5.991$

The table value of chi square for two degree of freedom at 5\% level of significance is 5.991. The calculated value of chi square is 21.3 more than the table value, hence null hypothesis is rejected. It means there is significant relationship of household congestion (noise) and having kids. It can be inferred as a matter of fact that factual information in table also shows that there is a significant difference of household congestion (noise) and having kids in home.

\section{CONCLUSIONS}

From the above data it is concluded that people during times of COVID 19 are not very satisfied with telecommuting. They face many problems of lack of motivation (specially in third week of telecommuting), reduction in trustworthiness, lacking team spirit, difficulty in following a disciplined work routine, feeling of disconnectedness from workplace, problems due to lack of equipments \& irritation due to lack of face to face meeting.

It was also concluded that poor internet connection affects performance and kids at home can be a source of household congestion (noise)

Few advantages include reduced traffic congestion and commuter hassles, higher productivity and better work-family balance

VIII. RECOMMENDATIONS:

1. The right of Telecommuting to be kept informed of their specific conditions of employment; 
2. The application of national laws and regulations concerning minimum age for admission to employment;

3. The fixing of minimum rates of wages for telecommuters;

4. The protection of occupational safety and health;

5. Hours of work, rest periods and leave;

6. Social security and maternity protection;

7. Protection in the case of termination of employment;

8. Support of training and other programmes specifically targeted at telecommuters.

\section{REFERENCES}

[1] Acharya, P., Mahanty, B. (2007). Manpower shortage crisis in Indian information technology industry. International Journal of Technology Management, 38(3), 235-247.

[2] André Fernandes Bernardino I; Karina De Déa Roglio II; Jansen Maia Del Corso III (August-2012).

[3] Bailey, D.E., Kurland, N.B. (2002). A review of telework research, findings, new directions, and lessons for the study of modern work. Journal of Organization Behavior, 23(4), 383-400.

[4] Golden, T.D., Veiga, J.F. (2005). The impact of extent of telecommuting on job satisfaction: Resolving inconsistent findings, Journal of Management, 31(2), 301-318.. 